\title{
研究ノ一ト
}

\section{アルミニウム電解着色における着色電解時間と 着色皮膜の色の濃さ}

\author{
佐藤敏彦* ・針塚聰一* ・和田昭人*

\begin{abstract}
Relationship Between the Electrolyzing Time and Deepness of Color in the Electrolytic Coloring of Anodized Aluminum
\end{abstract}

Toshihiko SATO, Toshikazu HARIZUKA and Akito WADA

\section{1. 緒言}

アルミニウム陽極酸化皮膜の電解着色に沏ける着色電 解時間と着色皮膜の色の濃さの関係について検討した。

\section{2. 実験試料及び方法}

アルミニウム試料としては純度 $99.5 \% \mathrm{Al}$ ，大きさ $2 \times$ $5 \times 0.03 \mathrm{~cm}$ のアルミニウム板を用いた。前処理は $5 \%$ 水酸化ナトリウム水溶液による脱脂の後, $30 \%$ 硝酸水溶 液による中和により行なった。アルミニウム陽極酸化皮 膜は $15 \mathrm{wt} \%$ 硫酸水溶液中で $15 \mathrm{~V}$ 定電圧電解を 20 分間 行なって作成した。この陽極酸化皮膜の厚さは $9 \mu \mathrm{m}$ で あった。電解着色は $30 \mathrm{~g} / l \mathrm{NiSO}_{4} \cdot 7 \mathrm{H}_{2} \mathrm{O}-30 \mathrm{~g} / l \mathrm{H}_{3} \mathrm{BO}_{3}$ 混合水溶液中で同面積の白金対極を用いて交流実効電圧 （50 Hz）12.5Vで定電圧電解により行なった。着色皮 膜の色の濃さは日本電色工業秘製色差計 ND-K 6 B によ り測定したL值で示した。アルミニウム陽極酸化皮膜へ のニッケル析出量は電解着色皮膜を $20 \%$ 塩酸水溶液中に 浸せきして,アルミニウム陽極酸化皮膜と皮膜中のニッ ケルを溶解し, この水溶液中のニッケル量を原子吸光光 度法で定量分析して行なった。

\section{3. 実験 結果}

図 1 は交流電解着色を行なっているとさの電流-時間 曲線を示す。交流実効電流值は電解時間に対して単調に 減少している。

図 2 は交流電解着色時間と着色皮膜の色の濃さの関保 を示す。交流電解着色開始後 4 分までは急激に着色皮膜 の色が濃くなっているが，その後の色の変化はゆるやか

* 芝浦工業大学（港区芝浦 3 の 9 の 14）

Shibaura Institute of Technology 3-9-14, Shibaura, Minato-ku, Tokyo
である。

図 3 は交流電解着色時間とアルミニウム陽極酸化皮膜 中へのニッケル析出量の関係を示す。交流電解開始後10 分まではニッケル析出量の急激な增加が認められるが, その後, ニッケル析出量はゆるやかに増加する。

\section{4. 考察}

電流-時間曲線之着色皮膜の色の濃さの関係及び電流時間曲線とニッケル析出量の関係は, いずれも一致した 傾向は示していない。图 1 の電流值は交流実効電流であ るのでアノード電流とカソード電流の面積平均值である し，また，電解着色浴中でのカソード反応はニッケルイ オンと水素イオンの競争還元反応であるので, 着色皮膜 の色の濃さやニッケル析出量と着色電解時間は比例しな かったものと思われる。

色の濃さとニッケル析出量の関係をグラフにプロット しても直線関係は得られなかった。ニッケル析出量が少 量のときはL值の変化は著しかったが，更にニッケル析 出量が増加してもL值の減少は小さかった。電解着色皮 膜の色の原因をアルミニウム陽極酸化皮膜の孔中に析出 した金属コロイドによる光の散乱であると考えるなら ば1),2， ある程度以上の大きさのコロイド粒径になると コロイド分散による色の変化は著しくないといらことで L值とニッケル析出量の関係が説明できるであろう。

ここで, アルミニウム陽極酸化皮膜の 1 つの孔中への ニッケル析出量を計算してみた。Wood ら ${ }^{3)}$ の研究によ ると硫酸浴によるアルミニウム陽極酸化皮膜の平均孔密 度は $7 \times 10^{10}$ 個 $/ \mathrm{cm}^{2}$, 平均孔直径は $150 \AA$ である。酸化 皮膜中への析出物がニッケル化合物ではなくて, 金属二 ッケルの円柱状粒子であると仮定して, ニッケルの比重 を8.9として計算した。交流電解時間 30 秒の着色皮膜の 場合, ニッケル析出量は $9.95 \times 10^{-4} \mathrm{~g} / \mathrm{cm}^{2}$ であったので, 


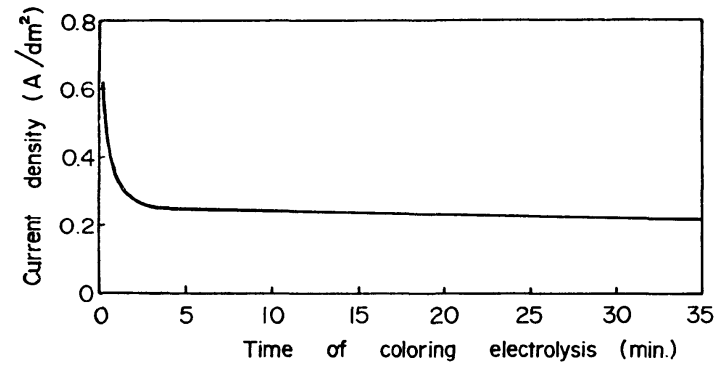

Fig. 1 Current density of coloring electrolysis plotted against time of coloring electrolysis.

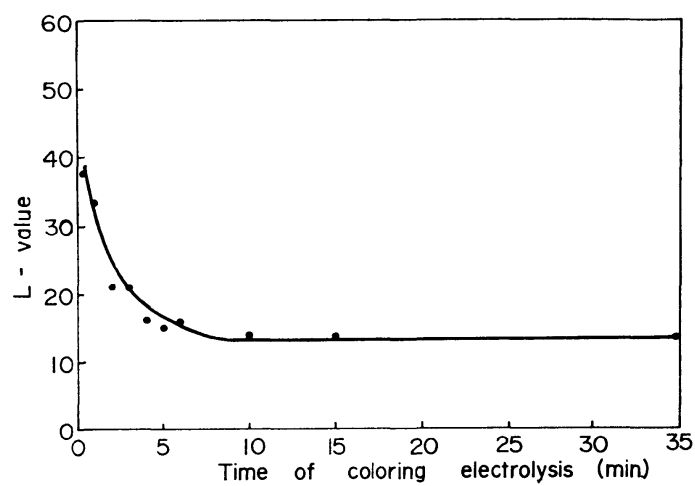

Fig. 2 L-values of colored films plotted against time of coloring electrolysis.

ニッケル析出物の大きさは $0.89 \mu \mathrm{m} \times 150 \AA ̊ \AA$ であった。 交流電解時間35分の着色皮膜の場合, ニッケル析出物の

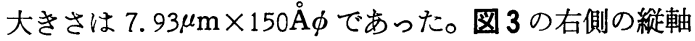
目盛は上記の計算法により計算した円柱状ニッケル析出 物の長さを示す。アルミニウム陽極酸化皮膜の厚さは9 $\mu \mathrm{m}$ であるので, 35 分の交流電解着色時間で多孔質層は ニッケルでほとんど充てんされることになる。

な拈, Woodら ${ }^{4)}$ はシュウ酸浴でアルミニウムを陽極

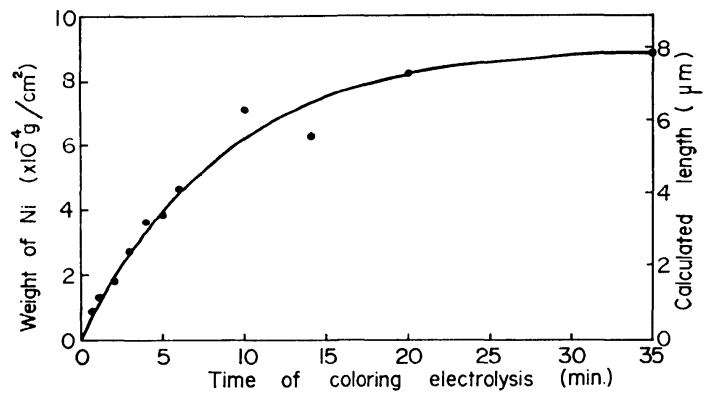

Fig. 3 Weight and calculated length of electrodeposited $\mathrm{Ni}$ plotted against time of coloring electrolysis.

酸化した試料を硝酸銀一硫酸混合水溶液中で電解着色し て, 析出物の大きさを電子顕徽鏡で観察している。Wood らの実験結果によると, アルミニウム陽極酸化皮膜の孔 中の析出物は $0.1 \mu \mathrm{m}$ から数 $\mu \mathrm{m}$ の大きさの柱状物質で あった。

(1976-7-23 受理)

\section{文献}

1) P. G. Sheasby, W. E. Cooke; The Electrolytic Coloring of Anodized Aluminium, Trans. Inst. Metal Finishing, 52, 103 (1974)

2）清水幹雄, 佐藤敏彦; 青色アルマイト，金属表面技 術協会第51回学術講演大会講演要旨集, P. 14(1975)

3) G. C. Wood, O'Sullivan; The Anodizing of Aluminium in Sulphate Solutions, Electrochim. Acta, 15, 1865 (1970)

4 ) A.S. Doughty, G.E. Thompson, J.A. Richardson, G.C.Wood ; Investigation of the Electrolytic Coloring of Porous Anodic Films on Aluminium using Electron Microscopy, Trans. Inst. Metal Finishing,

53, 33 (1975) 